\section{Nuclear actions}

On paper, at least, the world became a safer place last month, when Japan became the 96th nation to ratify the Non-Proliferation Treaty (NPT) while the Soviet Union and the USA signed a treaty limiting the size of single nuclear explosions "for peaceful purposes" to 150 kilotons or less. The USUSSR agreement was officially hailed as a major breakthrough because of its provision for on-site inspection by either party of single explosions over 100 kilotons or multiple explosions below the upper aggregate limit of 1,500 kilotons; this, it is claimed, could clear the way for future on-site monitoring of military test blasts.

But with no satisfactory conclusion to the Strategic Arms Limitation Talks in view, and no provision for on-site inspection in the 1974 threshold agreement on military tests (which forms the major part of the newly completed treaty), liberals regard the achievement sceptically, particularly as 150 kilotons is seen as a meaninglessly high limit. Both the military and nonmilitary treaties are expected to come

EXPERIMENTS with human subjects are increasingly being restricted by regulations and decrees. This is probbably just as well, as long as the pendulum doesn't swing too far. Vertebrates in general are now regarded with a kindly eye, unless they are considered to be edible. "The more I see of some people-any people-the better I like sea-lions". That is the cry. Experiments with Escherichia coli are getting a hard look. Soon we may hear that bacteria have rights, too. After all, the real difference between them and us is a disparity in the length and sequence of DNA molecules.

On the human scene, the California law-makers are pondering a bill (S2051) saying that various categories of people cannot give "informed consent" to experiments performed on their bodies. Included under this protective umbrella are prisoners. Graduate students are not mentioned; I noted this with some nostalgia, for I am a relict of an age when we assumed risks to gain benefits. Not any more. Let the other guy take the risks. And yet... as Charles Best said,

So now Banting and I rolled up our sleeves. I injected him with our extract and he injected me-we had to be sure it wasn't too toxic to be tolerated by human beings.

Someone, in December, 1921, had to be the first to be injected with insulin, so that many who could not, or did into force simultaneously following Senate ratification.

Japan's ratification of the NPT, ending a stormy six-year passage through the Diet, came as a result of strong US pressure, according to some Japanese government sources; US interests supply Japan with enriched uranium for her nuclear reactors. Japanese determination to achieve greater nuclear independence is, however, emphasised by its $\$ 8,400$ million nuclear fuel strategy aimed at securing an annual 21,700 tons of uranium oxide by 1995 . Japan hopes to build up 130 million kilowatts of nuclear power in place of petroleum over the next 20 years. By 1980 the proportion of domestic enrichment should have risen from 2 to $33 \%$.

Meanwhile, amid European plans to dump 6,700 of packaged radioactive wastes in 4,500 metres of Atlantic water next month, news broke of the first detected leak of plutonium from waste drums dumped off America over the past 20 years. Plutonium, a carcinogen threat, returns to man through the food chain.

not, give "informed consent" would benefit in years to come. The first patients to receive insulin did so without talking to their lawyers about malpractice suits.

\section{Human testing}

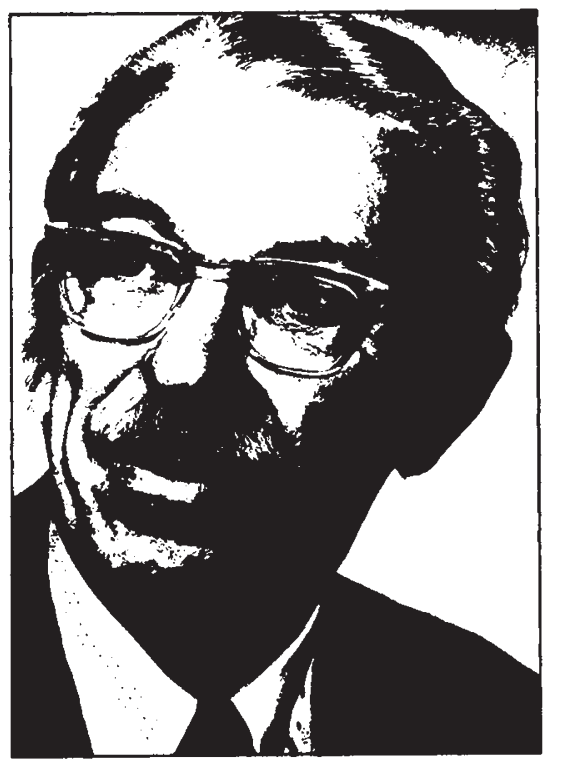

THOMAS H. JUKES

It was a romantic era; there were giants in those days. One was Howard Taylor Ricketts, who lifted five lice from a patient with typhus fever, and put them in his pocket in an envelope. When Ricketts opened the envelope

\section{Moves over fishing limits}

The agreement reached last week between Britain and Iceland to end the six months' old Third Cod War will itself last six months, during which Britain hopes to resolve two problems largely responsible for its interim character: the question of 200-mile international limits, which the unfinished UN Law of the Sea Conference will discuss further in August; and the matter of an EEC Common Fisheries Policy, on which the Nine seek agreement regarding wider exclusive national limits inside a 200-mile EEC "pond".

Delay on both has complicated the position of Norway as well as of Iceland, and she too may operate the 200-mile limit she seeks in the absence of an EEC agreement. Britain's special difficulty as the manoeuvring amongst the Nine continues is that her reported "target" limit, in the 35-50 mile range, though higher than the current 12mile exclusive limit, is far less than the 100 miles sought by British trawlermen. For all countries, however, the top priority remains the conservation of fish stocks.

later, in his laboratory, there were only four lice; the other one had escaped to his body. Ricketts died of typhus fever some days later. He was not the last to die of a laboratory infection while working on typhus, before it was brought under control by yolk-sac vaccine, DDT and tetracycline antibiotics. The US Public Health Service, Hamilton, Montana laboratory published a bulletin in the 1930 s that was dedicated by its authors to their colleagues who had died of Rocky Mountain spotted fever. The laboratory was conveniently near to a canyon that supplied ticks with a "hot strain" of the infective agent.

Prisoners often gave their informed consent to experiments performed on them. In some cases, their professed motivation was a desire to pay a debt that they thought they owed to society, rather than the hope of special privileges. The soldiers who volunteered to be bitten by mosquitoes that had fed on yellow-fever patients were compensated, if they survived, by sums of $\$ 300$. The widow of one of them received an annual pension of $£ 1,500$.

Most experiments with human subjects involved very little risk. I remember, as a graduate student, drinking a beaker of milk that had been liberally laced with staphlococcus toxin. Nothing happened, and I collected ten dollars. Gone are those bad old days; the lawyers and the government are looking after us. 